\title{
Risk analysis for cardiovascular complication based on the atherogenic index of plasma of type 2 diabetes mellitus patients in Medan, Indonesia
}

\author{
RINA AMELIA ${ }^{1, A-D, ~ g}, J U L I A N D I ~ H A R A H A P^{1, ~ B-D, ~ F, ~ A Z N A N ~ L E L O 2, ~ A, ~ D-G, ~ H E N D R I ~ W I J A Y A ~ 3, ~ A, ~ E-G ~}$ \\ ORCID ID: 0000-0002-1090-2003 ORCID ID: 0000-0002-3360-0120 ORCID ID: 0000-0002-7309-8227, \\ NOVITA SARI HARAHAP2, E-G, ZULHAM YAMAMOTO ${ }^{4, D-F}$ \\ ORCID ID: 0000-0002-4326-4001 ORCID ID: 0000-0002-8773-807X
}

\begin{abstract}
${ }^{1}$ Department of Community Medicine/Public Health, Faculty of Medicine, Universitas Sumatera Utara, Medan, Indonesia

${ }^{2}$ Department of Pharmacology and Therapeutics, Faculty of Medicine, Universitas Sumatera Utara, Medan, Indonesia

${ }^{3}$ Department of Pediatrics, Faculty of Medicine, Universitas Sumatera Utara, H. Adam Malik General Hospital, Indonesia

${ }^{4}$ Department of Histology, Faculty of Medicine, Universitas Sumatera Utara, Medan, Indonesia
\end{abstract}

A - Study Design, B - Data Collection, C - Statistical Analysis, D - Data Interpretation, E - Manuscript Preparation, F - Literature Search, G - Funds Collection

Summary Background. The main cause of mortality and morbidity in type 2 diabetes mellitus (T2DM) patients is cardiovascular disease. According to the American Heart Association, at least $65 \%$ of the deaths of T2DM patients are due to heart disease and stroke. Objectives. This study aims to analyse cardiovascular complication risk based on Atherogenic Index of Plasma (AIP) and the influencing factors in T2DM patients.

Material and methods. This is an analytical research design with a cross-sectional approach. The population of this study was T2DM patients from primary health care in Medan, Indonesia, with a total of 85 people. Subjects were recruited using consecutive sampling with inclusive and exclusive criteria. AIP values were determined using the AIP calculator with the logarithm calculation (TG/HDL-C). The chi-square test was used for statistical analysis, with a $95 \%$ confidence interval and a significant value of $p<0.05$.

Results. The majority of patients are known to be at high risk with AIP $\geq 0.21$. There is a relationship between $\mathrm{FBGL}$ and $\mathrm{HbA} \mathrm{A}_{1 \mathrm{c}}$ with AIP $(p<0.05)$. There is a significant relationship between TC, TG, HDL-C, LDL-C and AIP index $(p<0.05)$, while there is no relationship between LDL-C and AIP $(p>0.05)$.

Conclusions. A continuous educational effort is critical for improving patients' understanding in preventing the occurrence of complications that increase morbidity and mortality.

Key words: arteriosclerosis, dyslipidemias, type 2 diabetes mellitus.

Amelia R, Harahap J, Lelo A, Wijaya H, Harahap NS, Yamamoto Z. Risk analysis for cardiovascular complication based on the atherogenic index of plasma of type 2 diabetes mellitus patients in Medan, Indonesia. Fam Med Prim Care Rev 2020; 22(3): 197-201, doi: https:// doi.org/10.5114/fmpcr.2020.98242

\section{Background}

The main cause of mortality and morbidity in type 2 diabetes mellitus (T2DM) patients is cardiovascular disease. According to the American Heart Association, at least $65 \%$ of the deaths of T2DM patients are due to heart disease and stroke [1]. It is predicted than T2DM patients have a 2-4 times higher risk of cardiovascular disease than non-diabetes patients [2]. The mechanism of cardiovascular disorders in T2DM cases is complex and is related to arteriosclerosis, which is influenced by many factors, such as hypertension, hyperglycaemia, dyslipidaemia, smoking and obesity [3].

Dyslipidaemia is a common disorder found in T2DM patients. Patients with good control of diabetes still have a higher risk of heart disease [4]. Dyslipidaemia is one of the main risk factors of arteriosclerosis and cardiovascular disorders. It is related to the abnormality of lipid profiles in the plasma. Several main lipid fraction disorders are caused by an increase of Total Cholesterol (TC), Triglycerides (TG), Low Density Lipoprotein-
-Cholesterol (LDL-C) levels, as well as a decrease of High Density Lipoprotein-Cholesterol (HDL-C). Diabetes patients have a probability of Lipoprotein-Cholesterol (LDL) glycation, which causes oxidation of LDL molecules and the formation of arteriosclerosis plaque $[5,6]$.

Atherogenic index of plasma (AIP) is considered as the strength index of atherogenicity plasma, and it is positively correlated with cardiovascular disease [7]. AIP is also an indicator to determine patients' cardiovascular complications. Moreover, it becomes the therapeutic monitoring parameters for cardiovascular disorders in diabetes mellitus patients [8]. AIP value is an accurate predictor and prognostic factor of acute coronary heart disease as confirmed by angiography as the gold standard diagnostic test [9]. In addition, AIP is far better compared to the other traditional assessment indexes, such as the cardiogenic risk ratio and atherogenic coefficient, in analysing CVD incident risk.

Atherogenic index of plasma (AIP) is defined as log basic 10 (TG/HDL-C). It is used to ease the assessment of the LDL-C 
measurement, which is the significant predictor of cardiovascular disease. AIP is positively correlated with the risk of cardiovascular disease. Previous studies showed that AIP increased in patients with a high risk of coronary arterial disease and is positively correlated with the HDL esterification fraction, which is the dependent marker of atherogenicities [10]. The determination of coronary artery disease risk based on AIP is categorised into low risk with AIP $<0.11$, medium risk with AIP 0.11-0.21 and high risk with AIP $>0.21$ [11].

\section{Objectives}

The objective of this study is to analyse cardiovascular complication risk based on AIP index and the factors influencing it in T2DM patients in Medan City.

\section{Material and methods}

\section{Study design and participants}

The study is of an analytical design with a cross-sectional approach. The total population of the study was 85 subject with T2DM in Medan, Indonesia. The single sampling formula was used to obtain the hypothesis for the proportion of a population. Subjects were recruited using consecutive sampling with inclusive and exclusive criteria.

The inclusion criteria in this study was T2DM patients who were willing to join the study and were able to carry out daily activities independently. Whereas the exclusion criteria were pregnant patients with T2DM, patients with complications (chronic inflammation and impaired consciousness) and patients with a history of heart disease and vascular abnormalities in the family (these were known through anamnesis and patients with no heart disease intervention/heart catheterisation).

\section{Measures}

The study data was based on primary data. Ethical clearance was obtained from the Research Ethics Committees, Faculty of Medicine, Universitas Sumatera Utara. All of the T2DM patients involved in the study signed an informed consent form. For anthropometry evaluation, body weight and height measurements were done, followed by BMI calculation for nutritional status determination. Blood pressure (BP) measurement was conducted after a 10-minute rest using a digital BP monitor (Omron). Subjects had been fasting for 10 hours prior to venous blood collection for Fasting Blood Glucose Level (FBGL) and lipid profiles, which were done by using a fully automatic spectrophotometer colorimeter, and the $\mathrm{HbA}_{1 \mathrm{c}}$ examination was done using the Doronad Affinity + Modified HPLC method.

AIP was determined using the AIP online Czeh calculator as $\log$ (TG/HDL-C) for atherogenic risk [12]. The results determined the risk of DM patients to suffer from cardiovascular complications, which was categorised into 3 levels, i.e. low risk (AIP $<0.11$ ), intermediate risk (AIP: 0.11-0.21) and increased risk (AIP > 0.21).

Data analysis was done using a computer with SPSS software. The chi square test was used for statistical analysis, with a $95 \%$ confidence interval. The $p$-value was considered significant if $p<0.05$.

\section{Ethical approval}

This work received a positive opinion from the Ethics Committee (N0.80/TGL/KEPK FK USU-RSHAM 2019).

\section{Results}

The number of T2DM patients who had fulfilled the inclusion and exclusion criteria in this study was 85 people (Table 1 ).

\begin{tabular}{|c|c|c|}
\hline Characteristics & $\begin{array}{l}\text { Frequency } \\
\text { (n) }\end{array}$ & $\begin{array}{l}\text { Percentage } \\
(\%)\end{array}$ \\
\hline $\begin{array}{l}\text { Gender } \\
\text { male } \\
\text { female }\end{array}$ & $\begin{array}{l}16 \\
67\end{array}$ & $\begin{array}{l}19.3 \\
80.7\end{array}$ \\
\hline $\begin{array}{l}\text { Age group } \\
36-45 \text { years } \\
46-55 \text { years }\end{array}$ & $\begin{array}{l}12 \\
71\end{array}$ & $\begin{array}{l}14.5 \\
83.5\end{array}$ \\
\hline $\begin{array}{l}\text { Duration of illness } \\
\quad<5 \text { years } \\
6-10 \text { years } \\
11-15 \text { years } \\
>15 \text { years }\end{array}$ & $\begin{array}{l}50 \\
20 \\
11 \\
2\end{array}$ & $\begin{array}{l}60.2 \\
24.1 \\
13.3 \\
2.4\end{array}$ \\
\hline $\begin{array}{l}\text { Diabetes history } \\
\text { father } \\
\text { mother } \\
\text { father and mother } \\
\text { none }\end{array}$ & $\begin{array}{l}15 \\
15 \\
8 \\
45\end{array}$ & $\begin{array}{l}18.1 \\
18.1 \\
9.6 \\
54.2\end{array}$ \\
\hline $\begin{array}{l}\text { Body Mass Index (BMI) } \\
\text { underweight } \\
\text { normal weight } \\
\text { obesity }\end{array}$ & $\begin{array}{l}8 \\
43 \\
34 \\
\end{array}$ & $\begin{array}{l}9.4 \\
50.6 \\
40 \\
\end{array}$ \\
\hline $\begin{array}{l}\text { Blood pressure (systole) } \\
\text { hypertension } \\
\text { non-hypertension }\end{array}$ & $\begin{array}{l}66 \\
17 \\
\end{array}$ & $\begin{array}{l}79.5 \\
20.5 \\
\end{array}$ \\
\hline $\begin{array}{l}\text { Physical activity } \\
\text { high } \\
\text { medium } \\
\text { low }\end{array}$ & $\begin{array}{l}19 \\
13 \\
53\end{array}$ & $\begin{array}{l}22.4 \\
15.3 \\
62.4\end{array}$ \\
\hline $\begin{array}{l}\text { AIP } \\
\text { low risk }(<0.11) \\
\text { intermediate risk }(0.11-0.20) \\
\text { high risk }(\geq 0.21)\end{array}$ & $\begin{array}{l}29 \\
9 \\
47\end{array}$ & $\begin{array}{l}34.1 \\
10.6 \\
55.3\end{array}$ \\
\hline
\end{tabular}

The majority of patients in the study were female, $67 \mathrm{pa}-$ tients $(80.7 \%)$, and most patients were $46-55$ years old $(83.5 \%)$. 50 people $(60.2 \%)$ had been suffering from T2DM for less than 5 years. Based on family history, a total of 45 people (54.2\%) did not have diabetes mellitus in their family history. Based on the BMI, 43 people (50.6\%) were categorised as obese. It was also known that 66 people (79.5\%) had hypertension. Based on physical activity data, the majority of patients $(62.4 \%)$ had low physical activity. Meanwhile, AIP calculation showed that 47 patients (55.3\%) were at high risk of cardiovascular complication.

\begin{tabular}{|l|l|l|}
\hline \multicolumn{3}{|l|}{ Table 2. Glycaemic control, lipid profiles and AIP mean values } \\
\hline Variable & Mean \pm SD & Min-Max \\
\hline FBGL $(\mathrm{mg} / \mathrm{dL})$ & $249 \pm 109.16$ & $87.00-600.00$ \\
\hline $\mathrm{HbA}_{1 \mathrm{C}}(\%)$ & $9.50 \pm 2.63$ & $5.30-15.80$ \\
\hline $\mathrm{TC}(\mathrm{mg} / \mathrm{dL})$ & $237.90 \pm 60.52$ & $148.00-456.00$ \\
\hline $\mathrm{TG}(\mathrm{mg} / \mathrm{dL})$ & $214.70 \pm 184.68$ & $52.00-1,223.00$ \\
\hline $\mathrm{HDL}-\mathrm{C}(\mathrm{mg} / \mathrm{dL})$ & $45.50 \pm 11.15$ & $19.00-75.00$ \\
\hline $\mathrm{LDL}-\mathrm{C}(\mathrm{mg} / \mathrm{dL})$ & $150.30 \pm 56.37$ & $39.00-375.00$ \\
\hline AIP & $0.23 \pm 0.34$ & $-0.45-1.45$ \\
\hline TD Systole $(\mathrm{mm} \mathrm{Hg})$ & $153.5 \pm 20.1$ & $109-196$ \\
\hline TD Diastole $(\mathrm{mm} \mathrm{Hg})$ & $85 \pm 12.1$ & $61-120$ \\
\hline BMI $\left(\mathrm{kg} / \mathrm{m}^{2}\right)$ & $24.4 \pm 4.3$ & $15.2-36.9$ \\
\hline
\end{tabular}

FBGL - fasting blood sugar level; $\mathrm{HbA}_{1 \mathrm{c}}>8 \%$; TC - total cholesterol; TG - triglycerides; HDL-C - high density lipoprotein-cholesterol; LDL-C - low density lipoprotein-cholesterol; AIP - atherogenic index of plasma. DM (FBSL $\geq 126 \mathrm{mg} / \mathrm{dL}$ ), dyslipidaemia (TC > $200 \mathrm{mg} / \mathrm{dL}, \mathrm{TG}>150 \mathrm{mg} /$ $/ \mathrm{dL}, \mathrm{HDL}-\mathrm{C}<40 \mathrm{mg} / \mathrm{dL}, \mathrm{LDL}-\mathrm{C}>130 \mathrm{mg} / \mathrm{dL}$.

Table 2 shows the mean value of FBGL being $249 \mathrm{mg} / \mathrm{dl}$, $\mathrm{HbA}_{1 \mathrm{c}}$ is $9.5 \%$, and control lipid for TC, TG HDL-C, LDL-C, LDL-C 


\begin{tabular}{|c|c|c|c|c|}
\hline \multirow[t]{2}{*}{ Lipid profile } & \multicolumn{3}{|c|}{ AlP category } & \multirow[t]{2}{*}{$p$} \\
\hline & low & intermediate & high & \\
\hline $\begin{array}{l}\text { FBGL (mg/dl) } \\
80-99 \text { (good control) } \\
100-125 \text { (adequate control) } \\
\geq 126 \text { (lack of control) }\end{array}$ & $\begin{array}{l}2(6.9) \\
4(13.8) \\
23(79.3)\end{array}$ & $\begin{array}{l}0(0) \\
0(0) \\
9(100)\end{array}$ & $\begin{array}{l}1(2.1) \\
1(2.1) \\
45(95.7)\end{array}$ & 0.142 \\
\hline $\begin{array}{l}\mathrm{HbA}_{1 \mathrm{c}} \\
<6.5 \text { (good control) } \\
6.5-8 \text { (adequate control) } \\
\geq 8 \text { (lack of control) }\end{array}$ & $\begin{array}{l}7(24.1) \\
3(10.3) \\
19(65.5) \\
\end{array}$ & $\begin{array}{l}1(11.1) \\
2(22.2) \\
6(66.7)\end{array}$ & $\begin{array}{l}5(10.6) \\
12(25.5) \\
30(63.8) \\
\end{array}$ & 0.360 \\
\hline $\begin{array}{l}\text { TC }(\mathrm{mg} / \mathrm{dl}) \\
<200 \text { (good control) } \\
200-239 \text { (adequate control) } \\
\geq 240 \text { (lack of control) }\end{array}$ & $\begin{array}{l}17(58.6) \\
6(20.7) \\
6(20.7) \\
\end{array}$ & $\begin{array}{l}2(22.2) \\
2(22.2) \\
5(55.6) \\
\end{array}$ & $\begin{array}{l}8(17.0) \\
14(29.8) \\
25(53.2) \\
\end{array}$ & 0.004 \\
\hline $\begin{array}{l}\mathrm{HDL}-\mathrm{C}(\mathrm{mg} / \mathrm{dl}) \\
\text { good control }(\geq 45) \\
\text { bad control }(<45)\end{array}$ & $\begin{array}{l}25(86.2) \\
4(13.8)\end{array}$ & $\begin{array}{l}6(66.7) \\
3(33.3)\end{array}$ & $\begin{array}{l}10(21.3) \\
37(78.7)\end{array}$ & 0.0001 \\
\hline $\begin{array}{l}\text { LDL-C (mg/dl) } \\
<100 \text { (good control) } \\
100-129 \text { (adequate control) } \\
\geq 130 \text { (lack of control) }\end{array}$ & $\begin{array}{l}4(13.8) \\
12(41.4) \\
13(44.8) \\
\end{array}$ & $\begin{array}{l}0(0) \\
4(44.4) \\
5(55.6)\end{array}$ & $\begin{array}{l}7(14.9) \\
10(21.3) \\
30(63.8) \\
\end{array}$ & 0.242 \\
\hline $\begin{array}{l}\text { TG (mg/dl) } \\
150 \text { (good control) } \\
150-199 \text { (adequate control) } \\
200 \text { (lack of control) }\end{array}$ & $\begin{array}{l}29(100) \\
0(0) \\
0(0) \\
\end{array}$ & $\begin{array}{l}4(44.4) \\
3(33.3) \\
2(22.2)\end{array}$ & $\begin{array}{l}2(4.3) \\
17(36.2) \\
28(59.6)\end{array}$ & 0.0001 \\
\hline $\begin{array}{l}\text { Blood pressure (systole) } \\
\text { Normal (<140 mm Hg) } \\
\text { Hypertension ( } \geq 140 \mathrm{~mm} \mathrm{Hg} \text { ) }\end{array}$ & $\begin{array}{l}5 \text { (83.3) } \\
1(16.7)\end{array}$ & $\begin{array}{l}1(25.0) \\
3(75.0)\end{array}$ & $\begin{array}{l}10(62.5) \\
6(37.5)\end{array}$ & 0.177 \\
\hline $\begin{array}{l}\text { Physical Activity } \\
\text { High ( } \geq 1,500 \mathrm{MET}-\mathrm{min} / \text { week) } \\
\text { Medium (600-1500 MET-min/week) } \\
\text { Low (<600 MET-min/week) }\end{array}$ & $\begin{array}{l}6(20.7) \\
6(20.7) \\
17(58.6)\end{array}$ & $\begin{array}{l}1(11.1) \\
1(11.1) \\
7(77.8)\end{array}$ & $\begin{array}{l}12(25.6) \\
5(10.6) \\
30(63.8)\end{array}$ & 0.644 \\
\hline
\end{tabular}

is $237.90 \mathrm{mg} / \mathrm{dL}, 214.7 \mathrm{mg} / \mathrm{dL}, 45.50 \mathrm{mg} / \mathrm{dL}, 150.30 \mathrm{mg} / \mathrm{dL}$, respectively. The mean AIP value is 0.23 , and the mean systole and diastolic BP is $153.5 \mathrm{~mm} \mathrm{Hg}$ and $85 \mathrm{~mm} \mathrm{Hg}$, respectively. Finally, the $\mathrm{BMI}$ average is $24.4 \mathrm{~kg} / \mathrm{m}^{2}$. Patients were categorised into good, adequate and bad control T2DM from the mean values of the glycaemic control and lipid profiles.

To determine the relationship between risk factors for cardiovascular complications and AIP values in T2DM patients, an analysis was performed using the chi-square test (Table 3 ).

\section{Discussion}

Dyslipidaemia is a common disorder found in T2DM patients, as they have the probability of having denser and smaller LDL particles. These particles are normally formed from high triglycerides levels and high LDL-C and low HDL-C levels - usually known as triad diabetic dyslipidaemia [5]. A study in India showed a comparison of the lipid profiles of diabetics and healthy individuals. There is a negative correlation between Fasting Blood Glucose Level (FBGL) and HDL-C and a positive correlation between FBGL and TC, TG and LDL-C [13].

This study shows that a majority of patients ( 81 people $-95.3 \%$ ) are suffering from dyslipidaemia, and only 4 of them $(4.7 \%)$ are not. This result is aligned with a previous study that reported 282 patients (94\%) were found to have dyslipidaemia, whereas $6 \%$ were not [14-16]. Several patients experienced an increase of single lipid fraction; however, most of them experienced an increase of multiple lipid fractions. A study carried out in Turkey stated that there is an abnormality in lipid in T2DM patients, which is indicated by hypercholesterolemia, an LDL increase and an HDL decrease. An increase of total cholesterol serum, TG and LDL was found to be significant [17]. Dyslipidaemia is one of the main risk factors of atherosclerosis, which is the cause of macro- and micro-vascular disorders that increase the risk of cardiovascular complications in T2DM patients [14, 18]. According to the American Heart Association in 2015, at least $65 \%$ of the deaths of DM patients were due to heart disease and stroke. Besides this, adults suffering from DM have a 2-4 times higher risk of suffering from heart disease compared to non-diabetics $[1,19,20]$.

AIP is a strong indicator to predict atherosclerosis risk and cardiovascular disease. However, there are other indices used to predict CVD, such as the Framingham Heart Score and Atherosclerotic Cardiovascular Disease (ASCVD), recommended by the American Diabetes Association Standard of Diabetes Care (ADA), which, respectively, each have their own calculation rule. AIP is considered as a good and sensitive predictor for atherosclerosis and cardiovascular diseases in diabetics [8, 21]. AIP is a logarithmic transformation ratio from triglyceride molar concentration to HDL-cholesterol. The strong correlation of AIP with lipoprotein particle size can explain its high predictive value. AIP values increase with increased CVD risk. AIP comprehensively reflects the balance between atherogenic and anti-atherogenic factors [22]. From various researchers who have carried out studies before, AIP has proven to be a reliable marker for predicting CAD risk. AIP is categorised into low, intermediate and high risk of cardiovascular disorders [14]. The result of this study showed that 47 patients $(55.3 \%$ ) had a high risk of cardiovascular complications based on AIP value. This result is aligned with the previous studies, where 298 patients (99.3\%) were found to be at high risk [14].

AIP, the logarithm of the TG molar ratio to HDL-C, was first described by Dobiá sová and Frohlich in 2001. AIP has stronger sensitivity that reflects interactions between atherogenic and protective lipoproteins; therefore, AIP can be considered 
as an economical and reliable CAD indicator. There are several advantages to using AIP in clinical applications. First, after logarithmic transformation, AIP can correct the lack of a normal distribution. Second, the value of AIP can be obtained by direct calculation and does not require additional costs. Third, AIP can indirectly function as a substitute for LDL particle size [23]. AIP as a new sign of atherogenicity AIP is directly related to the risk of atherosclerosis [23]. Hypertriglyceridemia will increase liver lipase activity, which increases K-HDL catabolism (K-HDL degradation). AIP has a higher forecasting value for atherosclerosis, and several comparative figures for atherogenic markers, when divided by K-HDL, will increase the Odds ratio value, which is a higher forecast for atherosclerosis [22].

According to AIP research, it is considered a good predictor of atherosclerosis and a very sensitive risk predictor of CVD [24]. AIP values indicate a substantial agreement with the results of coronary angiography and are used to predict acute coronary events and prognosis in patients with acute myocardial infarction. AIP is superior to other traditional assessment indices (e.g. the ratio of cardiogenic risk and atherogenic coefficient) in assessing the risk for CV events. AIP is also considered to be able to predict the risk of T2DM. Risk factors associated with increased AIP are closely related to those for CVD and cerebrovascular disease in patients with T2DM. Compared to risk factors associated with CVD and cerebrovascular disease, the factors associated with increased AIP are more conducive to monitoring and follow-up. AIP is related to the particle size of antiatherosclerotic lipoproteins. Thus, this measure reflects the balance between protective and atherogenic lipoproteins [24].

In addition to AIP, there is a risk calculator, according to the American College of Cardiology/American Heart Association ASCVD (Risk Estimator Plus), which is generally a useful tool for estimating the risk of a 10-year ASCVD [25]. The American Diabetes Association Standard of Diabetes Care authorises the use of a risk factor-based approach to decide on the initiation of statin therapy. It recommends risk stratification, including three variables: age, the presence of previous cardiovascular events and the presence or absence of risk factors. Risk factors for ADA include: LDL-c above $100 \mathrm{mg} / \mathrm{dl}$, high blood pressure, smoking, being overweight/obese and a family history of premature ASCVD. All patients with definite ASCVD events should receive high-intensity statin therapy, regardless of age. In patients between 40 and 75 years without ASCVD events, but with a presence of cardiovascular risk factors, high-intensity statin therapy is recommended [26]. The risk of early ASCVD may be an important confounder and explanation for conflicting results in patients with type 2 diabetes mellitus. Accurate assessment of individual risk can be valuable in guiding and facilitating the prevention of ASCVD. In early 1976, the Framingham Heart Study identified several risk factors and developed a risk equation for first coronary heart disease. Since then, several tools for CVD risk evaluation have been published and have guided the practice [27].
This study then analyses the relationship between AIP with other risk factors of cardiovascular diseases. Based on the result, there is a relationship between FBS and $\mathrm{HbA}_{1 \mathrm{c}}$ with AIP $(p<0.05), \mathrm{TC}, \mathrm{HDL}-\mathrm{C}, \mathrm{LDL}-\mathrm{C}$ with AIP, and only LDL-C is not correlated with AIP. Meanwhile, previous research showed a positive correlation between FBS, TC, TG, LDL-C and AIP and a negative correlation between HDL-C and AIP [14].

The results of this study show that based on AIP values (AIP $>0.21), 47$ patients (55.3\%) are at high risk of cardiovascular complications, whereas the previous study showed 298 people $(99.3 \%)$ were at high risk [14]. AIP is related to waist size, waist-hip ratio, BMI, physical activities, age, BP, FBG and insulin resistance index (HOMA - IR), which is the risk factors of morbidity and mortality from the disease $[3,21,28]$. AIP is an independent predictor and a determinant of death in patients with acute myocardial infarction treated in hospitals [9].

A previous study stated that diabetes patients are at higher risk of atherosclerotic plaque with higher AIP [29]. Besides this, patients with higher AIP have higher uremic acid. It has been identified that there is a significant correlation between AIP and UA, with UA as a risk factor for AIP. A number of research studies showed that UA level serum is related to CVD, obesity, dyslipidaemia, hypertension and a disturbance of glucose metabolism. High UA serum contributes to several chronic metabolic diseases, including diabetes and coronary heart disease. The close relationship between UA and metabolic disease may be directly related to the endothelial dysfunction effect, oxidative stress and inflammation or may be indirectly related to several risk factors of metabolic syndrome [23, 30]. Several studies have shown that patients with type 2 diabetes mellitus and an increase of AIP are at higher risk of microalbuminuria, and AIP is an early detector of diabetic neuropathy [24].

\section{Conclusions}

Based on the study results and the discussion, we conclude that there is a relationship between FBS and $\mathrm{HbA}_{1 \mathrm{c}}$ with AIP $(p<0.05)$. There is a significant relationship between TC, TG, HDL-C, LDL-C and AIP index $(p<0.05)$, while there is no relationship between LDL-C and AIP ( $p>0.05)$. A continuous educational effort is very important in increasing patients' understanding in order to prevent the occurrence of complications which increase morbidity and mortality. An educational approach is highly recommended to improve patients' understanding and thus encouraging them to be more independent in controlling their disease to prevent any complications and have a better quality of life.

Acknowledgments. The authors would like to thank the Republic of Indonesia Ministry of Research, Technology and Higher Education for supporting this study.

Source of funding: This research was funded by the Republic of Indonesia Ministry of Research, Technology and Higher Education DRPM 2019, Number: 22/UN5.2.3.1/PPM/KP-DRPM/2019.

Conflicts of interest: The authors declare no conflicts of interest.

\section{References}

1. Davies MJ, D'Alessio DA, Fradkin J, et al. Management of hyperglycemia in type 2 diabetes, 2018. A consensus report by the American Diabetes Association (ADA) and the European Association for the Study of Diabetes (EASD). Diabetes Care 2018; 41(12): 2669-2701.

2. Yang SH, Du Y, Li XL, et al. Triglyceride to high-density lipoprotein cholesterol ratio and cardiovascular events in diabetics with coronary artery disease. Am J Med Sci 2017; 354(2): 117-124.

3. Bo MS, Cheah WL, Lwin S, et al. Understanding the relationship between atherogenic index of plasma and cardiovascular disease risk factors among staff of an University in Malaysia. J Nutr Metab 2018; 2018(3): 1-6, doi: 10.1155/2018/7027624.

4. Younis NN, Soran H, Sharma R, et al. Small-dense LDL and LDL glycation in metabolic syndrome and in statin-treated and non-statintreated type 2 diabetes. Diab Vasc Dis Res 2010; 7(4): 289-295.

5. Rabbani N, Godfrey L, Xue M, et al. Glycation of LDL by methylglyoxal increases arterial atherogenicity: a possible contributor to increased risk of cardiovascular disease in diabetes. Diabetes 2011; 60(7): 1973-1980. 
6. Noviyanti F, Decroli E, Sastri S. Perbedaan Kadar LDL-kolesterol pada Pasien Diabetes Melitus Tipe 2 dengan dan tanpa Hipertensi di RS Dr. M. Djamil Padang Tahun 2011. Jurnal Kesehatan Andalas 2015; 4(2): 545-550.

7. Khazaal MS. Atherogenic Index of Plasma (AIP) as a parameter in predicting cardiovascular risk in males compared to the conventional dyslipidemic indices (cholesterol ratios). Karbala J Med 2013; 6(1): 1506-1513.

8. Li Z, Huang $Q$, Sun $L$, et al. Atherogenic index in type 2 diabetes and its relationship with chronic microvascular complications. International Journal of Endocrinology 2018; 2018(3): 1-9, doi: 10.1155/2018/1765835.

9. Hartopo AB, Arso IA, Setianto BY. Low plasma atherogenic index associated with poor prognosis in hospitalized patients with acute myocardial infarction. Acta Medica Indonesiana 2016; 48(2): 106-113.

10. Momin AA, Bankar MP, Bhoite GM. Glycosylated hemoglobin (HbA1C): association with dyslipidemia and predictor of cardiovascular diseases in type 2 diabetes mellitus patients. Int J Health Sci Res 2013; 3(8): 40-46.

11. Ni W, Zhou Z, Liu T, et al. Gender-and lesion number-dependent difference in "atherogenic index of plasma" in Chinese people with coronary heart disease. Scientific Reports 2017; 7(1): 1-6, doi: 10.1038/s41598-017-13267-6.

12. Aip Calculator [online]. Available in URL: http://www.biomed.cas.cz/fgu/aip/kalkulator.php.

13. Kamble PM, Choudhari SC, Yadav AS. Study of lipid profile, oxidative stress, and antioxidant status, in type-2 diabetes mellitus. Walawalkar International Medical Journal 2015; 2(21): 28-36.

14. Anjum M, Uddin MS, Tamanna NA, et al. Evaluation of lipid profile pattern and atherogenic index of plasma (AIP) having type-2 diabetes mellitus in Bangladesh. International Journal of Research in Medical Sciences 2018; 6(3): 776, doi: 10.18203/2320-6012. ijrms20180595.

15. Amelia R, Damanik HA, Lindarto D, et al. The correlation between the level of HbA1c with total serum cholesterol of uncontrolled Type 2 Diabetes Mellitus patients in Binjai, Sumatera Utara. Adv Sci Lett 2017; 23(4): 3610-3613.

16. Amelia R, Harahap J, Wahyuni AS, et al. Health status of elderly based on daily activities living, cholesterol and uric acid profile in Medan city. InIOP Conference Series: Earth and Environmental Science 2018; 125(1): 012175.

17. Ozder A. Lipid profile abnormalities seen in T2DM patients in primary healthcare in Turkey: a cross-sectional study. Lipids Health Dis 2014; 13: 183, doi: 10.1186/1476-511X-13-183.

18. Martín-Timón I, Sevillano-Collantes C, Segura-Galindo A, et al. Type 2 diabetes and cardiovascular disease: have all risk factors the same strength? World J Diabetes 2014; 5(4): 444-470.

19. Cefalu WT. The journal of clinical and applied research and education. Diabetes Care 2017; 40(Suppl.): S1-S2.

20. Buse JB, Ginsberg HN, Bakris GL, et al. Primary prevention of cardiovascular diseases in people with diabetes mellitus: a scientific statement from the American Heart Association and the American Diabetes Association. Circulation 2007; 115(1): 114-126.

21. Juárez-Pérez CA, Aguilar-Madrid G, Haro-García LC, et al. Increased cardiovascular risk using atherogenic index measurement among healthcare workers. Arch Med Res 2015; 46(3): 233-239.

22. Nimmanapalli HD, Kasi AD, Devapatla PK, et al. Lipid ratios, atherogenic coefficient and atherogenic index of plasma as parameters in assessing cardiovascular risk in type 2 diabetes mellitus. Int J Res Med Sci 2016; 4(7): 2863-2869.

23. Cai G, Shi G, Xue S, et al. The atherogenic index of plasma is a strong and independent predictor for coronary artery disease in the Chinese Han population. Medicine (Baltimore) 2017; 96(37): e8058, doi: 10.1097/MD.0000000000008058.

24. Atalay H, Böyük B, Değirmencioğlu Ş, et al. Effect of the atherogenic index of plasma on microvascular complications associated with type 2 diabetes mellitus. Istanbul Med J 2015; 16(1): 111-115.

25. Arnett DK, Blumenthal RS, Albert MA, et al. ACC/AHA guideline on the primary prevention of cardiovascular disease: a report of the American College of Cardiology/American Heart Association Task Force on Clinical Practice Guidelines. JACC 2019; 74(10): e177-e232.

26. Bertoluci MC, Rocha VZ. Cardiovascular risk assessment in patients with diabetes. Diabetol Metab Syndr 2017; 9(1): 25, doi: 10.1186/ s13098-017-0225-1.

27. Zhang H, Qin L, Sheng CS, et al. ASCVD risk stratification modifies the effect of HbA1c on cardiovascular events among patients with type 2 diabetes mellitus with basic to moderate risk. BMJ Open Diabetes Res Care 2020; 8(1): e000810, doi: 10.1136/bmjdrc-2019-000810.

28. Niroumand S, Khajedaluee M, Khadem-Rezaiyan M, et al. Atherogenic Index of Plasma (AIP): a marker of cardiovascular. Med J Islam Repub Iran 2015; 29: 240.

29. Nansseu JR, Moor VJ, Nouaga ME, et al. Atherogenic index of plasma and risk of cardiovascular disease among Cameroonian postmenopausal women. Lipids Health Dis 2016; 15: 49, doi: 10.1186/s12944-016-0222-7.

30. Di CH, Rui DU, Yan WX, et al. Serum uric acid is associated with the predicted risk of prevalent cardiovascular disease in a communitydwelling population without diabetes. Biomed Environ Sci 2018; 31(2): 106-114.

Tables: 3

Figures: 0

References: 30

Received: 23.01 .2020

Reviewed: 14.02 .2020

Accepted: 22.07 .2020

Address for correspondence:

Rina Amelia, MD, PhD

Department of Community Medicine and Public Health

Faculty of Medicine

Universitas Sumatera Utara

Jl. dr. Mansyur No.5 Kampus USU Medan

20155 Medan

Indonesia

Tel.: +62 8126444284

E-mail: rina2@usu.ac.id 